\title{
EVALUASI PROGRAM WAJIB BELAJAR PENDIDIKAN DASAR DI DKI JAKARTA PADA PERIODE 2008-2011
}

\author{
HENRY ERYANTO* \\ \& DARMA RIKA $S^{*}$
}

\begin{abstract}
This study aimed to evaluate the Compulsory Basic Education Programme period 2008-2011 in Jakarta and knew the extent of the success of the program, and formulate policy recommendations to improve this activity in the future. This study uses the CIPP evaluation process to assess whether the program is appropriate to proceed or not. From the research, it is seen that in the context of the stage success indicators compulsory education program, it can be concluded that the implementation of the law that underlies the program has not done well. Referring to the input stage of program success indicators compulsory education, it can be concluded that the population of school age enrolled in school at that level has been well absorbed. Referring to the indicators of the success of the process stages of compulsory education program, it can be concluded that the stage of the process is quite successful. As well as referring to the indicators of the success of the product phase of compulsory education program, it can be concluded that the stage of successful products, because its value at a high level of completeness that range from 94 $\%-103 \%$
\end{abstract}

Keywords: Basic Education Programme, CIPP Evaluation, DKI Jakarta.

\section{PENDAHULUAN}

$\mathrm{Di}$

berkembang, perhatian utama terfokus pada pendidikan. Bahkan para founding fathers kita sadar sepenuhnya bahwa untuk

Henry Eryanto \& Darma Rika S. adalah dosen Fakultas Ekonomi Universitas Negeri Jakarta. membebaskan bangsa Indonesia dari kungkungan kebodohan dan kemiskinan, jalan satu-satunya adalah dengan pendidikan. Kesadaran tersebut dituangkan dalam rumusan Pembukaan UUD 1945 yang menegaskan bahwa salah satu tujuan pembangunan nasional adalah "mencerdaskan 
kehidupan bangsa". Selanjutnya, pada batang tubuh, pasal 31 UUD 1945 lebih tegas lagi menyatakan"(1) setiap warga negara berhak mendapatkan pendidikan", dan " (2) setiap warga negara wajib mengikuti pendidikan dasar dan pemerintah wajib membiayainya". Pada masa reformasi, dengan memperhatikan kondisi global, percepatan akselerasi pembangunan pendidikan menjadi prioritas utama pembangunan. Untuk mendasarinya, UndangUndang Dasar 1945 di amandemen dan pasal 31 UUD 1945 ditambah ayatnya.

Jika untuk meningkatkan pembangunan suatu bangsa diperlukan critical mass di bidang pendidikan, maka hal ini membutuhkan adanya persentase penduduk dengan tingkat pendidikan yang memadai untuk mendukung pembangunan ekonomi dan sosial yang cepat. Program pendidikan dasar sembilan tahun merupakan salah satu upaya pemerintah untuk mewujudkan critical mass itu dan membekali anak didik dengan ketrampilan dan pengetahuan dasar: untuk melanjutkan ke jenjang pendidikan yang lebih tinggi, untuk bekal menjalani kehidupan dalam masyarakat, untuk membuat pilihan-pilihan dan memanfaatkan produk-produk berteknologi tinggi, untuk mengadakan interaksi dan kompetisi antar warga masyarakat, kelompok, dan antar bangsa.

Program pendidikan dasar sembilan tahun atau yang lebih sering dikenal dengan Wajib belajar merupakan salah satu program yang gencar digalakkan oleh Departemen Pendidikan Nasional. Program ini mewajibkan setiap warga negara Indonesia untuk bersekolah selama 9 (sembilan) tahun pada jenjang pendidikan dasar, yaitu dari tingkat kelas 1 Sekolah Dasar (SD) atau Madrasah Ibtidaiyah (MI) hingga kelas 9 Sekolah Menengah Pertama (SMP) atau Madrasah Tsanawiyah (MTs). Program ini menargetkan pada tahun 2008, semua warga negara Indonesia memiliki pendidikan minimal setara Sekolah Menengah Pertama dengan mutu yang baik. Dengan bekal itu, diharapkan seluruh warga negara Indonesia dapat mengembangkan dirinya lebih lanjut sehingga mampu memilih dan mendapatkan pekerjaan yang sesuai dengan potensi yang dimiliki, sekaligus berperan serta dalam kehidupan bermasyarakat, berbangsa, dan bernegara. 
Namun demikian, target penuntasan wajar 9 tahun akan terancam gagal karena kurang antisipasinya pemerintah terhadap kendala-kendala yang menghadang. Hal ini bisa kita lihat dan cermati dari berbagai pemberitaan di media massa tentang kurangnya sarana dan prasarana sekolah dan rusaknya sekolah di berbagai tempat. Dan belum tercukupinya guru yang berada di daerah-daerah tertentu.

Permasalahan Wajar 9 tahun tak hanya milik daerah pedalaman, perkotaan pun tak luput dari permasalahan penuntasan wajar 9 tahun, khususnya bagi warga miskin. Berdasarkan data BPS, pada tahun 2010 tercatat Angka Partisipasi Sekolah (APS) umur 1315 tahun adalah $86,24 \%$ dan buta huruf usia 15 tahun plus (15 th + ) adalah 7,09\%, buta huruf umur 10 tahun mencapai 6,34\%. Angkaangka yang menunjukkan masih ada hambatan dalam pelaksanaan wajar 9 tahun.

Permasalahan yang tidak kalah penting adalah kesadaran masyarakat akan arti pentingnya pendidikan. Sebab, salah satu penyebab ketidak berhasilan dari wajib belajar adalah rendahnya kesadaran masyarakat dalam ikut serta secara aktif dalam pendidikan.
Hal ini disebabkan rendahnya tingkat pendidikan para orang tua, dan budaya yang ada di lingkungannya.

Kemudian muncul wacana untuk menerapkan program wajib belajar 12 tahun, mengingat program tersebut mulai dilaksanakan pada tahun 2012 lalu, peneliti ingin melihat bagaimana implementasi atau pelaksanaan program wajib belajar yang sebelumnya, apakah sudah tercapai dengan baik atau tidak melihat dari indikator-indikator yang ada.

Dengan

berbagai permasalahan di atas lah, peneliti melihat hal tersebut dan merasa perlu diadakan evaluasi terhadap Program Wajib Belajar Pendidikan Dasar Di DKI Jakarta pada periode 2008-2011.

\section{Pembatasan Masalah}

Untuk mencapai hasil yang optimal, penelitian ini dibatasi pada masalah bagaimana evaluasi terhadap Program Wajib Belajar Pendidikan Dasar di DKI Jakarta Periode 2008 - 2011 dilihat dari aspek-aspek konteks, input, proses dan produk.

Evaluasi konteks bertujuan untuk mengidentifikasi Program Wajib Belajar Pendidikan Dasar 
yang dalam pelaksanaannya berdasarkan pada pedoman yang ada. Evaluasi input memiliki tujuan untuk mendeskripsikan dan mengkaji kelengkapan input program Wajar yaitu jumlah anggaran, pedoman/juklak/juknis, jumlah SDM pelaksana, serta sarana dan prasarana. Evaluasi proses bertujuan untuk menilai proses penyelenggaraan Program Wajib Belajar, ditinjau dari pelaksanaan program sebagai implementasi kebijakan wajib belajar pendidikan dasar termasuk kendala/hambatan. Evaluasi produk mempunyai tujuan untuk mendeskripsikan dan menilai outcome program Wajar Pendidikan Dasar periode tahun 2008-2011.

\section{Perumusan Masalah}

Berdasarkan latar belakang penelitian diatas, dirumuskan masalah sebagai berikut:

1. Bagaimanakah konteks perencanaan dan penyelenggaraan Program Wajib Belajar Dikdas ditinjau dari definisi, fungsi dan tujuan, penyelenggaraan, pengelolaan, evaluasi, penjaminan serta hak dan kewajiban masyarakat?

2. Bagaimanakah input Program Wajib Belajar ditinjau dari jumlah penduduk Sekolah 7-12 tahun dan 13-15 tahun?

3. Bagaimanakah proses Program Wajib Belajar, ditinjau dari pelaksanaan program, hambatan/kendala serta Angka Partisipasi Murni Sekolah Dasar (APM SD), Angka Partisipasi Murni di Sekolah Menengah Pertama (APM SMP) dan Angka Melek Huruf (AMH) penduduk usia 15-24 tahun?

4. Bagaimanakah produk Program Wajib Belajar, ditinjau dari outcome program yaitu pencapaian Angka Partisipasi Kasar (APK)?

\section{TINJAUAN PUSTAKA}

\section{Deskripsi Kebijakan Publik dan Kebijakan Pendidikan}

Kebijakan publik adalah istilah yang sudah tidak asing lagi bagi masyarakat karena istilah ini sudah sering di dengar dalam kehidupan sehari-hari. Bahkan di kalangan masyarakat kampus, kebijakan publik menjadi kajian khusus dalam kegiatan penelitian dan tulisan sehingga saat ini banyak para pakar menulis dan menerbitkan buku-buku yang membahas teori-teori kebijakan publik dengan penekanan yang 
berbeda-beda.dikarenakan masingmasing pakar mengkajinya berdasarkan isu, gejala dan masalah yang berkembang di lingkungan masyarakat. Parsons (2006) dalam bukunya mengatakan bahwa pertumbuhan kebijakan publik sebagai suatu kajian di dunia akademik diperkirakan mulai pada akhir tahun 1960 an.

Berdasarkan pendapat dari Parson ini tampaknya ketertarikan para akademisi untuk mengkaji bidang ini sudah cukup lama apalagi saat ini berbagai kajian dan penelitian kebijakan publik sedang ngetren di perguruan tinggi Indonesia terutama setelah reformasi tahun 1998 dimana tuntutan terhadap good governance pada pemerintah semakin menguat sehingga proses kebijakan public sejak mulai dirumuskan sampai dengan dievaluasi dilakukan bersama antara pemerintah dengan masyarakat. Sesuai dengan pendapat Gambhir Bhatta dalam Riant Nugroho (2009) "governance is the relationship between government and citizens that enable public policies and programs to be formulated, implemented and evaluated". Atau dengan pengertian lain, pemerintahan adalah hubungan antara pemerintah dengan masyarakat yang memungkinkan kebijakan publik dan program yang akan dirumuskan, dilaksanakan dan di evaluasi.

Kemudian Steven A.Peterson (2003) mengatakan bahwa yang dimaksud dengan kebijakan publik adalah: "Government action to address some problem". Maksudnya adalah: Berbagai tindakan pemerintah untuk menyelesaikan berbagai masalah. Selanjutnya menurut James Lester dan Robert Steward (2000) mendefinisikan Kebijakan publik adalah : "a process or a series or pattern of governmental activities or decisions that are design to remedy some public problem, either real or imagined", maksudnya adalah "satu proses atau satu seri atau pola kegiatan-kegiatan atau keputusankeputusan pemerintah yang dirancang untuk memperbaiki beberapa masalah umum, baik yang nyata atau yang tidak nyata.

Selanjutnya menurut Anderson (1978) dalam Islamy (2003) pengertian kebijakan publik adalah : "Public policies are those develoved by governmental bodies and officials". Maksudnya bahwa kebijakan publik adalah kebijakankebijakan yang dikembangkan oleh 
badan-badan dan pejabat pemerintah. Sedangkan menurut Dye (1972) dalam Wahab (1990), bahwa kebijakan publik adalah "whatever governments choose to do or not to do". atau dalam pengertian lain, kebijakan publik adalah apapun yang dipilih pemerintah untuk dilakukan dan tidak dilakukan. Pendapat yang hampir senada dikemukakan oleh Dunn (1994), ia mendefinisikan bahwa kebijakan publik adalah "a complex pattern of interdependent collective choice, including decisions not act, made by governmental bodies and official'.

Pengertian Dunn dapat dipahami bahwa kebijakan publik mengedepankan berbagai hal dengan berdasarkan pola-pola yang bersifat kolektif, komplek, dan saling ketergantungan, dilakukan tidak hanya oleh pejabat pemerintah, melainkan juga oleh lembaga pemerintah secara keseluruhan. Demikian juga Easten (1953) yang menyatakan bahwa kebijakan publik sebagai: the authoritative allocation of Values for the whole society". Yang artinya kebijakan publik adalah pengalokasian nilai-nilai secara sah/paksa kepada masyarakat.

Berbeda dengan Dunn dan Easten, Gerston (1995), mengungkapkan bahwa kebijakan publik adalah "an attempts to resolve public issues, question that most people believe should be decided by officials at the appropriate level of government national, state or local'. Pendapat Gerston tentang kebijakan publik lebih menekankan kepada upayaupaya yang diputuskan oleh pejabat pemerintah pada setiap tingkat pemerintahan. Pendapat yang hampir sama dikemukakan oleh Parker (1975), bahwa kebijakan publik adalah "suatu tujuan tertentu atau serangkaian prinsip atau tindakan yang dilakukan oleh pemerintah dalam periode tertentu berkaitan dengan suatu subyek atau tanggapan terhadap suatu krisis".

Sementara Lasswell dan Kaflan (1970) mendefinisikan kebijakan sebagai: "a projected program of goals, values, and practies", dan menurut Friedrich (1963) bahwa "it is essential for the policy concept that there be a goal, objective, or purposes". Definisi yang lebih lengkap dikemukakan oleh William Jenkins dalam bukunya Policy Analiysis: A Political and Organization Perspective yang dikutip Howlett and Ramesh (1995) bahwa kebijakan publik sebagai "a set of interrelated decision taken by 
a political actor or group of actors concerning the selection of goals and the means of achieving them within a specified situation where those decision should, in principal, be within the power of those actors to acieve". (Howlett, Michael and Ramesh, M., 1995; 5).

Jones (1984) yang mengutip pendapat Eula dan Prewitt, berpendapat hampir senada dengan Gerston dengan mengemukakan bahwa kebijakan publik sebagai keputusan tetap yang dicirikan oleh konsistensi dan pengulangan tingkah laku dari mereka yang membuat dan dari mereka yang mematuhi keputusan tersebut.

Jika Eula dan Prewitt memahami kebijakan penekanannya kepada keputusan-keputusan itu sendiri, Edward III dan Sharkansky (1978) berbeda, ia mengemukakan bahwa kebijakan adalah apa yang dilakukan dan tidak dilakukan oleh pemerintah memiliki tujuan dan maksud yang jelas dan merupakan program-program pemerintah yang akan dilaksanakan. Nakamura dan Smallowood (1980), hampir senada dengan Eula dan Prewitt, menurutnya bahwa kebijakan public adalah "serangkaian instruksi kepada para pembuat kebijakan yang menjelaskan tujuan dan cara- cara untuk mencapai tujuan tersebut".

Demikian juga Pressman dan Wildavsky (1984) berpendapat bahwa kebijakan sebagai: "a hypotesis containing initial condition and predicted consequences". Dengan kata lain bahwa kebijakan merupakan suatu hipotesis yang mengandung kondisi-kondisi awal dan akibat-akibat yang dapat diramalkan.

Secara umum, dari beberapa definisi yang dikemukakan di atas, dapat disimpulkan bahwa pandangan mengenai kebijakan publik terbagi ke dalam Dua kelompok. Pertama, kelompok yang memandang kebijakan publik sebagai suatu tindakan atau apaapa yang sebenarnya dilakukan; kedua, kelompok yang menekankan bahwa kebijakan publik merupakan suatu rangkaian keputusan.

Dengan demikian, dari beberapa pendapat pakar kebijakan publik tersebut di atas dapat disimpulkan bahwa kebijakan publik merupakan suatu rangkaian keputusan yang dibuat oleh individu, lembaga atau pemerintah mengenai urusan publik yang mengarahkan tindakan yang mempunyai tujuan, sasaran, dan maksud tertentu sebagai upaya 
mengatasi permasalahan publik agar menjadi lebih baik dan sesuai dengan yang diharapkan.

Dalam konteks penelitian ini yang dimaksud dengan kebijakan publik adalah rangkaian perundangundangan atau keputusankeputusan mengenai pendidikan nasional, khususnya tentang penyelenggaraan Program Wajib Belajar Pendidikan Dasar.

\section{Evaluasi Program \\ Pengertian}

Menurut Wirawan (2011), evaluasi di bidang pendidikan ada 2 macam yaitu : evaluasi hasil belajar dan evaluasi program pendidikan. Lebih lanjut Wirawan mengatakan bahwa "evaluasi belajar bertujuan untuk mengukur apakah pembelajaran berbagai bidang ilmu mencapai tujuan yang telah ditentukan oleh kurikulum pembelajaran ilmu tersebut. Evaluasi ini dilakukan melalui pekerjaan rumah, ulangan umum, dan ujian nasional. Evaluasi program pendidikan untuk mengevaluasi berbagai aspek pendidikan misalnya, kurikulum, proses dan metode pembelajaran mata pelajaran, layanan pendidikan, tenaga pendidikan dan sebagainya".
Dalam membicarakan evaluasi seringkali kita menemukan kata-kata yang berhubungan dengan kata evaluasi, menurut Suharsimi Arikunto (2012), "kata yang selalu berkaitan dengan kata evaluasi tersebut adalah: evaluasi (evaluation), pengukuran (measurement), dan penilaian (assessment)." Ditambahkan pula oleh Arikunto bahwa, "Evaluasi adalah kegiatan untuk mengumpulkan informasi tentang bekerjanya sesuatu, yang selanjutnya informasi tersebut digunakan untuk menentukan alternatif yang tepat dalam mengambil keputusan.

Menurut Stufflebeam, dkk (1971) dalam Suharsimi (2007) mendefinisikan evaluasi sebagai "the process of delineating, obtaining, and providing useful information for judging decision alternatives," Artinya evaluasi merupakan proses menggambarkan, memperoleh, dan menyajikan informasi yang berguna untuk merumuskan suatu alternatif keputusan.

Tyler, Fernandes (1984) mengemukakan bahwa, evaluasi adalah suatu proses untuk menentukan seberapa jauh tujuan pendidikan dapat dicapai. 
Sementara itu, Kaufman \& Thomas (1980) "evaluation is a process of helping to make things better than they are, of improving the situation", evaluasi adalah suatu proses untuk membantu dan memperbaiki sesuatu menjadi lebih baik dari keadaan sebelumnya

Dan menurut Anne Anastasi (1978) mengartikan evaluasi sebagai "a systematic process of determining the extent to which instructional objective are achieved by pupils". Evaluasi bukan sekadar menilai suatu aktivitas secara spontan dan insidental, melainkan merupakan kegiatan untuk menilai sesuatu secara terencana, sistematik, dan terarah berdasarkan tuiuan yang jelas.

Menurut Wirawan (2011), "Pada awal 1930 Ralph Winfred Tyler yang kemudian dikenal sebagai bapak evaluasi ia mengemukakan definisi dan teorinya mengenai evaluasi yang memfokuskan pada menilai apakah tujuan suatu program tercapai atau tidak yang kemudian dikenal sebagai Goal based evaluation model."

Sedangkan program menurut Suharsimi Arikunto (2012), "program adalah suatu rencana yang melibatkan berbagai unit yang berisi kebijakan dan rangkaian kegiatan yang harus dilakukan dalam kurun waktu tertentu". Masih menurut Arikunto (2009), "Program adalah suatu kegiatan yang direncanakan dengan seksama". Sedangkan menurut Tayibnasis (2000), "program adalah segala sesuatu yang dicoba lakukan seseorang dengan harapan akan mendatangkan hasil atau pengaruh".

Dilanjutkan oleh Suharsimi Arikunto (2012) bahwa, "Evaluasi program adalah suatu unit atau kesatuan kegiatan yang bertujuan mengumpulkan informasi tentang realisasi atau implementasi dari suatu kebijakan, berlangsung dalam proses yang berkesinambungan, dan terjadi dalam suatu organisasi yang melibatkan sekelompok orang guna pengambilan keputusan". Jadi evaluasi program merupakan rangkaian kegiatan yang dilakukan dengan sengaja dan secara cermat untuk mengetahui tingkat keterlaksanaan atau keberhasilan suatu program dengan cara mengetahui efektivitas masingmasing komponennya, baik terhadap program yang sedang berjalan maupun program yang telah berlalu.

\section{Dimensi Evaluasi Program}

Setelah kita menentukan obyek evaluasi selanjutnya harus 
menentukan aspek-aspek dari obyek yang akan evaluasi. Menurut Stake, 1967, Stuffebeam, 1959, Alkin 1969 (dalam Suharsimi, 2007) telah mengemukakan bahwa evaluasi berfokus pada empat aspek yaitu :
a. Konteks
b. Input
c. Proses implementasi
d. Produk

Bridgman dan Davis (dalam Farida Yusuf, 2000) yaitu evaluasi program yang secara umum mengacu pada 4 (empat) dimensi yaitu :
a. Indikator input,35
b. Indikator process,
c. Indikator outputs
d. Indikator outcomes.

Menurut Beni Setiawan (1999) Direktorat Pemantauan dan Evaluasi Bapenas, tujuan evalusi program adalah agar dapat diketahui dengan pasti apakah pencapaian hasil, kemajuan dan kendala yang dijumpai dalam pelaksanaan program dapat dinilai dan dipelajari untuk perbaikan pelaksanaan program dimasa yang akan datang.

Menurut Beni Setiawan, (1999) dimensi utama evaluasi diarahkan kepada hasil, manfaat, dan dampak dari program. Pada prinsipnya yang perlu dibuat perangkat evaluasi yang dapat diukur melalui empat dimensi yaitu :

a. indikator masukan (input),

b. Proses (process)

c. keluaran (output),

d. indikator dampak atau (outcame)

\section{Tujuan Evaluasi Program}

Adapun tujuan dari evaluasi program menurut Suharsimi Arikunto (2007) adalah "untuk mengetahui pencapaian tujuan program yang telah dilaksanakan. Selanjutnya, hasil evaluasi program digunakan sebagai dasar untuk melaksanakan kegiatan tindak lanjut atau untuk melakukan pengambilan keputusan berikutnya".

Evaluasi sama artinya dengan kegiatan supervisi. Kegiatan evaluasi atau supervisi dimaksudkan untuk mengambil keputusan atau melakukan tindak lanjut dari program yang telah dilaksanakan. Manfaat dari evaluasi program dapat berupa penghentian program, merevisi program, melanjutkan program, dan menyebarluaskan program.

$$
\text { Menurut Jones (1984), }
$$

"Implementation of the program should always be evaluated to see how far the program has managed to achieve program objectives previously set". Artinya Implementasi program harus senantiasa dievaluasi untuk melihat 
sejauh mana program tersebut telah berhasil mencapai tujuan program yang telah ditetapkan sebelumnya.

Jadi tanpa adanya evaluasi, program-program yang berjalan tidak akan dapat dilihat efektifitasnya. Dengan demikian, kebijakan-kebijakan baru sehubungan dengan program itu tidak akan didukung oleh data. Karenanya, evaluasi program bertujuan untuk menyediakan data dan informasi serta rekomendasi bagi pengambil kebijakan (decision maker) untuk memutuskan apakah akan melanjutkan, memperbaiki atau menghentikan sebuah program".

\section{Model-model Evaluasi Program}

Pada penelitian ini model evaluasi yang diadopsi yaitu menurut Kaufan dan Thomas dalam Suharisimi Arikunto (2007) yang membedakan model evaluasi program menjadi delapan, yaitu:

1. Goal Oriented Evaluation Model Objek pengamatan model ini adalah tujuan dari program. Evaluasi dilaksanakan berkesinambungan, terusmenerus untuk mengetahui ketercapaian pelaksanaan program.

2. Goal Free Evaluation Model
Dalam melaksanakan evaluasi tidak memperhatikan tujuan khusus program, melainkan bagaimana terlaksananya program dan mencatat hal-hal yang positif maupun negatif.

3. Formatif Summatif Evaluation Model

Model evaluasi ini dilaksanakan ketika program masih berjalan (evaluasi formatif) dan ketika program sudah selesai (evaluasi sumatif).

4. Countenance Evaluation Model

Model ini juga disebut model evaluasi pertimbangan. Maksudnya evaluator mempertimbangkan program dengan memperbandingkan kondisi hasil evaluasi program dengan yang terjadi di program lain, dengan objek ssaran yang sama dan membandingkan kondisi hasil pelaksanaan program dengan standar yang ditentukan oleh program tersebut.

5. Responsif Evaluation Model Model ini tidak dijelaskan dalam buku ini karena model ini kurang populer.

6. SSE-UCLA Evaluation Model

Model ini meliputi empat tahap, yaitu 
a. Needs assessment, memusatkan pada penentuan masalah hal-hal yang perlu dipetimbangkan dalam program, kebutuhan uang dibutuhkan oleh program, dan tujuan yang dapat dicapai.

b. Program planning, perencanaan program dievaluasi untuk mengetahui program disusun sesuai analisis kebutuhan atau tidak.

c. Formative evaluation, evaluasi dilakukan pada saat program berjalan.

d. Summative program, evaluasi untuk mengetahui hasil dan dampak dari program serta untuk mengetahui ketercapaian program.

7. CIPP Evaluation Model (Context Input Process Product)

a. Evaluasi Konteks

Evaluasi konteks adalah evaluasi terhadap kebutuhan, tujuan pernenuhan dan karakteristik individu yang menangani. Seorang evaluator harus sanggup menentukan prioritas kebutuhan dan memilih tujuan yang paling menunjang kesuksesan program.

b. Evaluasi Masukan

Evaluasi masukan mempertimbangkan kemampuan awal atau kondisi awal yang dimiliki oleh institusi untuk melaksanakan sebuah program.

c. Evaluasi Proses

Evaluasi proses diarahkan pada sejauh mana program dilakukan dan sudah terlaksana sesuai dengan rencana.

d. Evaluasi Hasil

Ini merupakan tahap akhir evaluasi dan akan diketahui ketercapaian tujuan, kesesuaian proses dengan pencapaian tujuan, dan ketepatan tindakan yang diberikan, dan dampak dari program.

8. Discrepancy Model

Model ini ditekankan untuk mengetahui kesenjangan yang terjadi pada setiap komponen program. Evaluasi kesenjangan dimaksudkan untuk mengetahui tingkat kesesuaian antara standar yang sudah ditentukan dalam program dengan penampilan aktual dari program tersebut.

Ketepatan penentuan model evaluasi program bergantung pada jenis kegiatannya. Oleh karena itu tidak semua model evaluasi program dapat diterapkan. Penelitian ini menggunakan model CIPP. Lebih lanjut peneliti mengemukakan konsep evaluasi berdasarkan model CIPP. 
Terdapat banyak model evaluasi program yang digunakan para ahli. Salah satunya adalah model CIPP ( Context - input process - product). Model ini dikembangkan oleh Stufflebeam. Model CIPP (1971) melihat kepada empat dimensi yaitu dimensi Konteks, dimensi Input, dimensi Proses dan dimensi Produk.

\section{Pendidikan}

Pendidikan adalah usaha
sadar dan terencana untuk
mewujudkan suasana belajar dan
proses pembelajaran agar peserta
didik secara aktif mengembangkan
potensi dirinya untuk memiliki
kekuatan spiritual keagamaan,
pengendalian diri, kepribadian,
kecerdasan, akhlak mulia, serta
keterampilan yang diperlukan
dirinya, masyarakat, bangsa dan
Negara.
Landasan pokok keberadaan
sistem pendidikan nasional adalah
UUD 45 Bab XIII, Pasal 31 , ayat (1)
Yang menyatakan bahwa: Tiap-tiap
warga negara berhak mendapatkan
pengajaran. Hal ini mengandung
implikasi bahwa sistem pendidikan
nasional harus mampu memberi
kesempatan belajar yang seluas-
luasnya kepada setiap warga
negara.

Di dalam UU Nomor 2 tahun 1989 disebutkan bahwa Tujuan Pendidikan Nasional, yaitu "Mencerdaskan kehidupan bangsa dan mengembangkan manusia Indonesia seutuhnya, yaitu manusia yang beriman dan bertakwa terhadap Tuhan Yang Maha Esa dan berbudi pekerti luhur, memiliki pengetahuan dan ketrampilan, kesehatan jasmani dan rohani, kepribadian yang mantab dan mandiri serta rasa tanggung jawab kemasyarakatan dan kebangsaan."

Sesungguhnya faktor tujuan bagi pendidikan adalah:

a. Sebagai Arah Pendidikan, tujuan akan menunjukkan arah dari suatu usaha, sedangkan arah menunjukkan jalan yang harus ditempuh dari situasi sekarang kepada situasi berikutnya.

b. Tujuan sebagai titik akhir, suatu usaha pasti memiliki awal dan akhir. Mungkin saja ada usaha yang terhenti karena sesuatu kegagalan mencapai tujuan, namun usaha itu belum bisa dikatakan berakhir. Pada umumnya, suatu usaha dikatakan berakhir jika tujuan akhirnya telah tercapai.

c. Tujuan sebagai titik pangkal mencapai tujuan lain, apabila tujuan merupakan titik akhir dari usaha, maka dasar ini merupakan titik 
tolaknya, dalam arti bahwa dasar tersebut merupakan fundamen yang menjadi alas permulaan setiap usaha.

d. Memberi nilai pada usaha yang dilakukan

\section{UUD}

1945

(versi

Amendemen), Pasal 31 , ayat 3 menyebutkan, "Pemerintah mengusahakan dan menyelenggarakan satu sistem pendidikan nasional, yang meningkatkan keimanan dan ketakwaan serta ahlak mulia dalam rangka mencerdaskan kehidupan bangsa, yang diatur dengan undang-undang." Pasal 31 , ayat 5 menyebutkan,

"Pemerintah memajukan ilmu pengetahuan dan teknologi dengan menunjang tinggi nilai-nilai agama dan persatuan bangsa untuk kemajuan peradaban serta kesejahteraan umat manusia."

Dalam semua UndangUndang Sistem Pendidikan Nasional yang pernah berlaku di Indonesia tersebut, dinyatakan bahwa pendidikan nasional merupakan alat dan sekaligus tujuan yang sangat penting dalam perjuangan mencapai cita-cita dan tujuan nasional.

\section{Evaluasi Program Wajib Belajar Konteks Wajib Belajar Pendidikan Dasar (Wajar Dikdas Sembilan Tahun)}

Program wajib belajar diselenggarakan untuk memberikan pelayanan pendidikan dasar seluasluasnya kepada warga negara Indonesia tanpa membedakan latar belakang agama, suku, sosial, budaya, dan ekonomi. Setiap warga negara Indonesia usia wajib belajar berhak mendapatkan pelayanan pendidikan yang bermutu dan orang tua/walinya berkewajiban memberi kesempatan kepada anaknya untuk mendapatkan pendidikan dasar.

Program wajib belajar diselenggarakan pada satuan pendidikan dasar pada jalur pendidikan formal, nonformal, dan informal dan harus dapat menampung anak yang normal maupun yang berkelainan dan mempunyai hambatan. Peraturan tentang program wajib belajar mencakup hak dan kewajiban warga negara Indonesia, tanggung jawab Pemerintah dan pemerintah daerah.

Undang-Undang No.20 Tahun 2003 tentang Sistem Pendidikan Nasional menyebutkan kewajiban belajar bagi semua rakyat Indonesia. Bahkan konsep wajib belajar di Indonesia sudah 
dicanangkan sejak tahun 1950 melalui Undang-Undang No.4 Th.1950. Akan tetapi secara formal pelaksanaan wajib belajar baru dimulai tahun 1984.

Pada awal pelaksanaannya, wajib belajar di Indonesia merupakan wajib belajar sekolah dasar (SD) enam tahun. Rincian wajib belajar tersebut tertuang dalam Bab-VII U.U. No.4 Th.1950 sebagai berikut: (1) semua anak yang sudah berumur 6 tahun berhak dan yang sudah berumur 8 tahun diwajibkan belajar di sekolah, sedikitnya selama 6 tahun; (2) belajar di sekolah agama yang sudah mendapat pengakuan dari Menteri Agama, dianggap telah memenuhi kewajiban belajar (Sogimin G, 2005).

Wajib belajar sekolah dasar 6 tahun tersebut rupanya dianggap telah tidak memadai lagi, maka pemerintah mencanangkan wajib belajar pendidikan dasar 9 tahun, terdiri atas 6 tahun sekolah dasar (SD) dan 3 tahun sekolah lanjutan tingkat pertama (SLTP). Pencanangan wajib belajar pendidikan dasar 9 tahun merupakabn realisasi U.U. No.2 Th.1989 dan pelaksanaannya dimulai tahun 1994. Dengan dilaksanakannya wajib belajar pendidikan dasar 9 tahun, maka SMP tercakup dalam pendidikan dasar.

$$
\text { Undang-Undang }
$$

No.2

Th.1989 tidak secara eksplisit memuat wajib belajar pendidikan dasar 9 tahun dalam bab tersendiri. Wajib belajar itu tertuang pada pasal 5 dan 6, serta secara khusus pada pasal 14 . Pasal 5 mengemukakan bahwa setiap warga negara mempunyai hak yang sama untuk memperoleh pendidikan, pasal 6 menyebutkan bahwa setiap warga negara berhak atas kesempatan yang seluas-luasnya untuk mengikuti pendidikan agar memperoleh pengetahuan, kemampuan, dan keterampilan yang sekurang-kurangnya setara dengan pengetahuan, kemampuan, dan keterampilan tamatan pendidikan dasar. Pasal 14 menyatakan bahwa warga negara yang berumur 6 tahun berhak mengikuti pendidikan dasar dan warga negara yang merumur 7 tahun berkewajiban mengikuti pendidikan dasar atau pendidikan yang setara, sampai tamat (Sogimin G, 2005.

Konteks mengenai program wajib belajar diadopsi dari Peraturan Pemerintah RI No.47 Tahun 2008 mengenai Wajib Belajar, antara lain: 


\section{Definisi}

1. Pasal 1 ayat 1 , definisi dari Wajib belajar adalah program pendidikan minimal yang harus diikuti oleh warga negara Indonesia atas tanggung jawab Pemerintah dan pemerintah daerah.

2. Pasal 1 ayat 2, definisi pendidikan dasar adalah jenjang pendidikan yang melandasi jenjang pendidikan menengah, berbentuk Sekolah Dasar (SD) dan Madrasah Ibtidaiyah (MI) atau bentuk lain yang sederajat serta sekolah menengah pertama (SMP) dan madrasah tsanawiyah (MTs), atau bentuk lain yang sederajat.

\section{Fungsi dan Tujuan}

1. Pasal 2 ayat 1 , Wajib belajar berfungsi mengupayakan perluasan dan pemerataan kesempatan memperoleh pendidikan yang bermutu bagi setiap warga negara Indonesia.

2. Pasal 2 ayat 2, Wajib belajar bertujuan memberikan pendidikan minimal bagi warga negara Indonesia untuk dapat mengembangkan potensi dirinya agar dapat hidup mandiri di dalam masyarakat atau melanjutkan pendidikan ke jenjang yang lebih tinggi.

Penyelenggaraan

1. Pasal 3 ayat 1 , Wajib belajar diselenggarakan pada jalur pendidikan formal, pendidikan nonformal, dan pendidikan informal.

2. Pasal 3 ayat 2 , Penyelenggaraan wajib belajar pada jalur formal dilaksanakan minimal pada jenjang pendidikan dasar yang meliputi SD, MI, SMP, MTs, dan bentuk lain yang sederajat.

3. Pasal 3 ayat 3 , Penyelenggaraan wajib belajar pada jalur pendidikan nonformal dilaksanakan melalui program paket $A$, program paket $B$, dan bentuk lain yang sederajat.

4. Pasal 3 ayat 4, Penyelenggaraan wajib belajar pada jalur pendidikan informal dilaksanakan melalui pendidikan keluarga dan/atau pendidikan lingkungan.

\section{Pengelolaan}

Pasal 6 ayat 3, Pengelolaan program wajib belajar pendidikan dasar tingkat kabupaten/kota menjadi tanggung jawab bupati/walikota.

\section{Evaluasi}

1. Pasal 8 ayat 1 , Pemerintah, pemerintah provinsi, dan 
pemerintah kabupaten/kota melakukan evaluasi terhadap pelaksanaan program wajib belajar secara berkala.

2. Pasal 8 ayat 2, Evaluasi terhadap pelaksanaan program wajib relajar sebagaimana dimaksud pada ayat (1) sekurangkurangnya meliputi:

a. tingkat pencapaian program wajib belajar;

b. pelaksanaan kurikulum pendidikan dasar;

c. hasil belajar peserta didik; dan

d. realisasi anggaran.

\section{Penjaminan Wajib Belajar}

1. Pasal 11 ayat 1 , Pemerintah dan pemerintah daerah menjamin tersedianya lahan, sarana, dan prasarana selain lahan pendidikan untuk setiap satuan pendidikan pelaksana program wajib belajar yang diselenggarakan oleh Pemerintah atau pemerintah daerah sesuai kewenangannya masing-masing, dengan pembagian beban tanggung jawab sebagaimana diatur dalam peraturan perundang-undangan yang mengatur tentang pendanaan pendidikan.
2. Pasal 11 ayat 2, Pemerintah dan pemerintah daerah menjamin tersedianya pendidik, tenaga kependidikan, dan biaya operasi untuk setiap satuan pendidikan penyelenggara program wajib belajar dengan pembagian beban tanggung jawab sebagaimana diatur dalam peraturan perundang-undangan yang mengatur tentang pendanaan pendidikan.

\section{Hak dan Kewajiban Masyarakat}

Pasal 13 ayat 1 , Masyarakat berhak:

a. berperan serta dalam perencanaan, pelaksanaan, pengawasan, dan evaluasi terhadap penyelenggaraan program wajib belajar; serta

b. mendapat data dan informasi tentang penyelenggaraan program wajib belajar.

Pasal 13 ayat 2, Masyarakat berkewajiban mendukung penyelenggaraan program wajib belajar.

\section{Input Wajib Belajar Pendidikan Dasar (Wajar Dikdas Sembilan Tahun) \\ Input mengenai program wajib belajar yaitu penduduk dengan usia yang sesuai pada sekolah tingkat dasar, yaitu}


penduduk usia Sekolah 7-12 tahun dan 13-15 tahun.

\section{Proses Wajib Belajar \\ Pendidikan Dasar (Wajar \\ Dikdas Sembilan Tahun)}

Pada tahap proses, penelitian ini meninjau dari indikator dari Goal 2 MDGs Millenium Development Goals BPS (Mencapai Pendidikan Dasar untuk Semua) pada target 3 yaitu: Angka Partisipasi Murni Sekolah Dasar (APM SD), Angka Partisipasi Murni di Sekolah Menengah Pertama (APM SMP), Proporsi murid kelas 1 yang berhasil mencapai kelas 5, Proporsi Murid Kelas 1 yang Berhasil Menamatkan Sekolah Dasar, Proporsi Murid Kelas 1 yang berhasil menyelesaikan sembilan tahun pendidikan dasar serta angka melek huruf penduduk usia 15-24 tahun.

Peneliti hanya mengambil 3 indikator yaitu Angka Partisipasi Murni Sekolah Dasar (APM SD), Angka Partisipasi Murni di Sekolah Menengah Pertama (APM SMP) dan Angka Melek Huruf (AMH) penduduk usia 15-24 tahun.

Angka partisipasi murni sekolah dasar adalah perbandingan antara murid sekolah dasar (SD), usia 7-12 tahun termasuk Madrasah Ibtidaiyah (MI), dengan penduduk usia 7-12 tahun, dinyatakan dalam persentase.

Rumus yang digunakan:

APM-SD=Banyaknya murid SD usia 7-12th x 100\%

Banyaknya penduduk usia 7-12th

Angka partisipasi murni sekolah menengah pertama adalah perbandingan antara murid SMP usia 13-15 tahun termasuk Madrasah Tsanawiyah (MTs) dengan penduduk usia 13-15 tahun, dinyatakan dalam persentase.

Rumus yang digunakan:

APM-SMP=Banyaknya murid SMP usia 13-15th x 100\%

Banyaknya penduduk usia $13-15$ tahun

Angka melek huruf penduduk usia 15-24 tahun adalah perbandingan jumlah penduduk berusia 15-24 tahun yang dapat membaca dan menulis kalimat sederhana dengan huruf latin dengan jumlah penduduk usia 15-24 tahun.

Rumus yang digunakan:

AMH 15-24=Byk pndduk usia 1524thn yang melek huruf $x 100$ Jumlah penduduk usia 15-24 tahun 


\section{Produk Wajib Belajar Pendidikan Dasar (Wajar Dikdas Sembilan Tahun)}

Produk Program Wajar Dikdas melihat dari indikator keberhasilan program, sesuai dengan indikator dari Goal 2 MDGs Millenium Development Goals BPS (Mencapai Pendidikan Dasar untuk Semua) pada target 3. Indikator yang dipakai pemerintah untuk mengukur ketercapaian Program Wajib Belajar 9 Tahun adalah pencapaian Angka Partisipasi Kasar (APK).

APK=jumlah siswa SMP/sederajat di suatu daerah $\times 100 \%$

Jumlah penduduk usia 13 - 15 tahun

Tingkat ketuntasan daerah dalam melaksanakan program Wajar Dikdas 9 Tahun dikategorikan:
a. Tuntas pratama, bila APK mencapai $80 \%$ s.d. $84 \%$
b. Tuntas madya, bila
APK mencapai $85 \%$ s.d. $89 \%$
c. Tuntas utama, bila APK mencapai $90 \%$ s.d. $94 \%$
d. Tuntas paripurna, bila APK mencapai minimal $95 \%$.

\section{Indikator Keberhasilan Program}

Penelitian ini menggunakan model evaluasi CIPP, maka peneliti melihat indikator keberhasilan dari setiap tahap, yaitu:

1. Tahap Context (Konteks), indikator keberhasilan tahap ini melihat pada terlaksana atau tidak implementasi hukum yang melandasi kebijakan program wajib belajar pendidikan dasar.

2. Tahap Input (Masukan), indikator keberhasilan tahap ini melihat pada rendah atau tingginya prosentase jumlah penduduk usia sekolah yang bersekolah.

3. Tahap Process (Proses), indikator keberhasilan tahap ini melihat pada rendah atau tingginya prosentase dari APM-SD, APM-SMP dan AMH.

4. Tahap Product (Produk), indikator keberhasilan tahap ini melihat pada tingkat ketuntasan daerah.

\section{METODE PENELITIAN}

Penelitian ini menggunakan metode atau pendekatan deduktif kualitatif, karena tujuannya adalah untuk mendeskripsikan dan menggambarkan apa adanya mengenai suatu variabel, gejala, keadaan atau fenomena sosial tertentu. Data kuantitatif yang berbentuk tabel-tabel dan berupa 
angka-angka yang dikumpulkan akan ditampilkan dilakukan analisis dan pembahasan secara detail, digunakan untuk mendukung analisis secara keseluruhan sebagai pembuktian bagi fenomenafenomena yang sedang diteliti, yang dalam hal ini tentang pelaksanaan Program Wajib Belajar dengan lokus di DKI Jakarta.

\section{Instrumen Penelitian}

\section{Definisi Konseptual}

Evaluasi program adalah kegiatan penilaian dalam rangka menguji tingkat kegagalan dan keberhasilan, kefektifan dan efisisensi terhadap pelaksanaan suatu program.

\section{Definisi Operasional}

Evaluasi program adalah kegiatan penilaian terhadap pelaksanaan Program Wajib Belajar yang diukur dengan indikator tiaptiap aspek yaitu:

1. Aspek konteks perencanaan dan penyelenggaraan Program Wajib Belajar ditinjau dari definisi, fungsi dan tujuan, penyelenggaraan, pengelolaan, evaluasi serta hak dan kewajiban masyarakat.

2. Aspek input Program Wajib Belajar ditinjau dari jumlah penduduk Sekolah 7-12 tahun dan 13-15 tahun.

3. Aspek proses Program Wajib Belajar, ditinjau dari pelaksanaan program serta hambatan/kendala serta dari indikator dari Goal 2 MDGs Millenium Development Goals BPS (Mencapai Pendidikan Dasar untuk Semua) pada target 3 . Peneliti hanya membatasi pada 3 Indikator yang digunakan adalah Angka Partisipasi Murni Sekolah Dasar (APM SD), Angka Partisipasi Murni di Sekolah Menengah Pertama (APM SMP) dan Angka Melek Huruf (AMH) penduduk usia 15-24 tahun..

4. Aspek produk Program Wajib Belajar, ditinjau dari outcome program serta dari indikator dari Goal 2 MDGs Millenium Development Goals BPS (Mencapai Pendidikan Dasar untuk Semua) pada target 3. Indikator yang dipakai pemerintah untuk mengukur ketercapaian Program Wajib Belajar 9 Tahun adalah pencapaian Angka Partisipasi Kasar (APK).

\section{Model Penelitian Evaluasi}

Peneliti menggunakan evaluasi model CIPP, karena 
berdasarkan pertanyaan penelitian, maka diperlukan informasi yang menyeluruh tentang pelaksanaan Program Wajib Belajar Pendidikan Dasar di DKI Jakarta. Mengingat model CIPP memberikan suatu format evaluasi yang komprehensif pada setiap tahapan pelaksanaan program, maka dalam penelitian ini ditetapkan untuk menggunakan evaluasi model CIPP.

\section{Instrumen Penelitian}

Penelitian ini rencananya akan menggunakan pendekatan deskriptif kualitatif. Data kualitatif didapatkan dengan wawancara dan observasi sedangkan kuantitatif didapatkan dari hasil perhitungan terhadap data yang relevan, baik data primer maupun sekunder yang mendasarkan pada aspek-aspek penelitian yang berkaitan dengan pelaksanaan Program Wajib Belajar Pendidikan Dasar di DKI Jakarta.

\section{Sumber Data}

1. Data Primer yaitu data yang diambil langsung dari responden menggunakan wawancara mengenai konteks, input, proses (hambatan/kendala) dan produk (outcome program).

2. Data Sekunder yaitu data yang diperoleh secara tidak langsung dari sumbernya, berupa data yang diperoleh dari Biro Pusat Statistik (BPS) dan Survei Sosial Ekonomi (Susenas). Secara spesifik data yang digunakan adalah sebagai berikut :

a. Konteks, ditinjau dari definisi, fungsi dan tujuan, penyelenggaraan, pengelolaan, evaluasi serta hak dan kewajiban masyarakat. Data bersumber dari PP No.47 Tahun 2008 tentang WajibBelajar dan Millenium Development Goals BPS (MDGs) Goal 2.

b. Input. Data yang digunakan adalah jumlah penduduk Sekolah 7-12 tahun dan 13-15 tahun. Data tersebut bersumber dari Biro Pusat Statistik.

c. Proses, ditinjau dari indikator dari Goal 2 MDGs Millenium Development Goals BPS (Mencapai Pendidikan Dasar untuk Semua) pada target 3. Peneliti hanya membatasi pada 3 Indikator yang digunakan adalah Angka Partisipasi Murni Sekolah Dasar (APM SD), Angka Partisipasi Murni di Sekolah Menengah Pertama (APM SMP) dan Angka Melek Huruf (AMH) penduduk usia 15-24 tahun. Data tersebut didapat melalui Biro Pusat Statistik. 
d. Produk, ditinjau dari indikator dari Goal 2 MDGs Millenium Development Goals BPS (Mencapai Pendidikan Dasar untuk Semua) pada target 3 . Indikator yang dipakai pemerintah untuk mengukur ketercapaian Program Wajib Belajar 9 Tahun adalah pencapaian Angka Partisipasi Kasar (APK).

\section{Teknik Pengumpulan Data}

Teknik pengumpulan data dalam penelitian akan menggunakan teknik sebagai berikut :

\section{Observasi atau pengamatan}

Pengumpulan data penelitian ini akan dilakukan melalui kegiatan observasi atau pengamatan langsung terhadap obyek analisis untuk menggali aspek-aspek yang relevan dan penting sebagai dasar analisis dan interpretasi yang akan dilakukan.

\section{Wawancara}

Wawancara dilakukan terhadap narasumber (key informan) yang dianggap memiliki pengetahuan yang memadai tentang suatu persoalan atau fenomena pelaksanaan Program Wajib Belajar Pendidikan Dasar di DKI Jakarta pada tahun 2008-2011.
Adapun Key Informan yang dimaksud adalah:

1. Pengawas Dikdas DKI Jakarta.

2. Para Kepala Sekolah SD dan SMP di DKI Jakarta

3. Para guru SD dan SMP di DKI Jakarta.

\section{HASIL DAN PEMBAHASAN \\ Evaluasi Context (Konteks) Program Wajar Dikdas}

Konteks mengenai program wajib belajar diadopsi dari Peraturan Pemerintah RI No.47 Tahun 2008 mengenai Wajib Belajar, antara lain:

\section{Definisi}

1. Pasal 1 ayat 1 , definisi dari Wajib belajar adalah program pendidikan minimal yang harus diikuti oleh warga negara Indonesia atas tanggung jawab Pemerintah dan pemerintah daerah.

2. Pasal 1 ayat 2, definisi pendidikan dasar adalah jenjang pendidikan yang melandasi jenjang pendidikan menengah, berbentuk Sekolah Dasar (SD) dan Madrasah Ibtidaiyah (MI) atau bentuk lain yang sederajat serta sekolah menengah pertama (SMP) dan madrasah 
tsanawiyah (MTs), atau bentuk lain yang sederajat.

\section{Fungsi dan Tujuan}

1. Pasal 2 ayat 1 , Wajib belajar berfungsi mengupayakan perluasan dan pemerataan kesempatan memperoleh pendidikan yang bermutu bagi setiap warga negara Indonesia.

2. Pasal 2 ayat 2 , Wajib belajar bertujuan memberikan pendidikan minimal bagi warga negara Indonesia untuk dapat mengembangkan potensi dirinya agar dapat hidup mandiri di dalam masyarakat atau melanjutkan pendidikan ke jenjang yang lebih tinggi.

\section{Penyelenggaraan}

1. Pasal 3 ayat 1 , Wajib belajar diselenggarakan pada jalur pendidikan formal, pendidikan nonformal, dan pendidikan informal.

2. Pasal 3 ayat 2, Penyelenggaraan wajib belajar pada jalur formal dilaksanakan minimal pada jenjang pendidikan dasar yang meliputi SD, MI, SMP, MTs, dan bentuk lain yang sederajat.

3. Pasal 3 ayat 3, Penyelenggaraan wajib belajar pada jalur pendidikan

nonformal dilaksanakan melalui program paket $A$, program paket $B$, dan bentuk lain yang sederajat.

4. Pasal 3 ayat 4, Penyelenggaraan wajib belajar pada jalur pendidikan informal dilaksanakan melalui pendidikan keluarga dan/atau pendidikan lingkungan.

\section{Pengelolaan}

Pasal 6 ayat 3, Pengelolaan program wajib belajar pendidikan dasar tingkat kabupaten/kota menjadi tanggung jawab bupati/walikota.

\section{Evaluasi}

1. Pasal 8 ayat 1 , Pemerintah, pemerintah provinsi, dan pemerintah kabupaten/kota melakukan evaluasi terhadap pelaksanaan program wajib belajar secara berkala.

2. Pasal 8 ayat 2 , Evaluasi terhadap pelaksanaan program wajib relajar sebagaimana dimaksud pada ayat (1) sekurangkurangnya meliputi:

a. tingkat pencapaian program wajib belajar;

b. pelaksanaan kurikulum pendidikan dasar;

c. hasil belajar peserta didik; dan

d. realisasi anggaran. 


\section{Penjaminan Wajib Belajar}

1. Pasal 11 ayat 1 , Pemerintah dan pemerintah daerah menjamin tersedianya lahan, sarana, dan prasarana selain lahan pendidikan untuk setiap satuan pendidikan pelaksana program wajib belajar yang diselenggarakan oleh Pemerintah atau pemerintah daerah sesuai kewenangannya masing-masing, dengan pembagian beban tanggung jawab sebagaimana diatur dalam peraturan perundang-undangan yang mengatur tentang pendanaan pendidikan.

2. Pasal 11 ayat 2 , Pemerintah dan pemerintah daerah menjamin tersedianya pendidik, tenaga kependidikan, dan biaya operasi untuk setiap satuan pendidikan penyelenggara program wajib belajar dengan pembagian beban tanggung jawab sebagaimana diatur dalam peraturan perundang-undangan yang mengatur tentang pendanaan pendidikan.

\section{Hak dan Kewajiban Masyarakat}

Pasal 13 ayat 1, Masyarakat berhak:
a. berperan serta dalam perencanaan, pelaksanaan, pengawasan, dan evaluasi

terhadap penyelenggaraan program wajib belajar; serta

b. mendapat data dan informasi tentang penyelenggaraan program wajib belajar.

Pasal 13 ayat 2, Masyarakat berkewajiban mendukung penyelenggaraan program wajib belajar.

\section{Evaluasi Konteks Program Wajib Belajar Pendidikan Dasar}

Beberapa hal yang dievaluasi dari konteks Program Wajar Dikdas ini, yaitu:

1. Berdasarkan definisi harusnya program ini merupakan program minimal yang harus diikuti dan merupakan tanggung jawab dari pemerintah dan pemerintah daerah. Pada kenyataannya tidak semua diwajibkan karena masih ada anak usia sekolah yang tidak bersekolah atau melanjutkan sekolah di tingkat pendidikan dasar, karena tidak ada sanksi yang jelas untuk hukum wajib tersebut.

2. Dalam hal fungsi dan tujuan, dimana Wajib belajar bertujuan memberikan pendidikan minimal bagi warga negara Indonesia untuk dapat mengembangkan potensi dirinya agar dapat hidup mandiri di dalam masyarakat 
atau melanjutkan pendidikan ke jenjang yang lebih tinggi, berdasarkan wawancara dengan key informan, masih ada yang melihat bahwa kompetensi lulusan pendidikan dasar belum bisa mandiri dan menggunakan kompetensinya dengan baik di dunia luar.

3. Dalam hal penyelenggaraan wajib belajar pada jalur pendidikan informal dilaksanakan melalui pendidikan keluarga dan/atau pendidikan lingkungan, berdasarkan hasil wawancara dapat disimpulkan bahwa pendidikan dasar di lingkungan keluarga masih kurang.

4. Dalam hal penjaminan wajib belajar yaitu pemerintah dan pemerintah daerah menjamin tersedianya lahan, sarana, dan prasarana selain lahan pendidikan untuk setiap satuan pendidikan pelaksana program wajib belajar yang diselenggarakan oleh Pemerintah atau pemerintah daerah sesuai kewenangannya masing-masing, masih ada sekolah-sekolah yang belum terpenuhi lahan dan sarana prasarana terutama sekolah swasta.

5. Pemerintah dan pemerintah daerah menjamin tersedianya pendidik, tenaga kependidikan, dan biaya operasi untuk setiap satuan pendidikan penyelenggara program wajib belajar dengan pembagian beban tanggung jawab, pada kenyataannya masih ada sekolah yang mengeluhkan karena banyak guru memasuki masa purna tugas maka ada kekosongan, tetapi ada larangan mengangkat guru honorer bagi sekolah negeri, sehingga penjaminan tersedianya pendidik tidak terpenuhi.

6. Konteksnya masyarakat dapat berperan serta dalam perencanaan, pelaksanaan, pengawasan, dan evaluasi terhadap penyelenggaraan program wajib belajar; serta mendapat data dan informasi tentang penyelenggaraan program wajib belajar. Tetapi, kenyataannya masyarakat tidak sepenuhnya ikut serta dalam tahapan-tahapan tersebut, terutama karena tidak mendapatkan sosialisasi dan penyuluhan mengenai pentingnya program tersebut agar kesadaran masyarakt dalam mendukung program wajar dikdas meningkat. 
Indikator Keberhasilan Tahap Konteks Program Wajib Belajar Pendidikan Dasar

Jika melihat dari beberapa evaluasi pada konteks program Wajib Belajar Pendidikan Dasar di atas, maka dapat disimpulkan bahwa implementasi hukum yang melandasi program tersebut belum terlaksana dengan baik.

Tabel 4.1 Evaluasi Input Program Wajar Dikdas

\begin{tabular}{|c|c|c|}
\hline Tahun & $\begin{array}{c}\text { Jumlah } \\
\text { Penduduk } \\
\text { Usia 7-12 } \\
\text { Tahun }\end{array}$ & $\begin{array}{c}\text { Jumlah } \\
\text { Penduduk } \\
\text { Usia 13-15 } \\
\text { Tahun }\end{array}$ \\
\hline 2008 & 758.052 & 403.147 \\
\hline 2009 & 866.345 & 409.702 \\
\hline 2010 & 884.025 & 418.063 \\
\hline 2011 & 928.226 & 438.966 \\
\hline
\end{tabular}

Sumber : Biro Pusat Statistik

Tahapan input dalam program wajib belajar pendidikan dasar adalah input dari program tersebut yaitu peserta didiknya yang merupakan penduduk dengan usia sekolah pendidikan dasar dari sekolah dasar (SD) dan sekolah menengah pertama (SMP) yaitu rentang usia 7-12 tahun untuk SD dan rentang usia 13-15 tahun untuk SMP. Melihat tabel di atas dapat kita ketahui bahwa input jumlah penduduk usia sekolah mengalami peningkatan tiap tahunnya, hal ini memang dapat terjadi karena bertambahnya penduduk dengan usia untuk dapat sekolah tiap tahunnya. Dimana ratarata kenaikan tiap tahunnya adalah $+1.5 \%-2 \%$.

\section{Evaluasi Input Program Wajib Belajar Pendidikan Dasar}

Beberapa hal yang dievaluasi dari input Program Wajar Dikdas ini, yaitu:

1. Antara input, proses dengan produk program wajib belajar pendidikan dasar saling berkaitan, jika melihat jumlah penduduk usia sekolah SMP yaitu 13-15 tahun mengalami peningkatan tiap tahunnya, tetapi jika dibandingkan antara APM-SMP dengan APK-SMP (pada tahap proses dan produk), tiap tahunnya APM-SMP lebih rendah dari APK-SMP, yang berarti ada anak di luar usia 1315 tahun bersekolah di tingkat tersebut, yaitu anak yang berusia dibawah 13 tahun dan di atas 15 tahun. Hal ini dapat terjadi karena sekolah tersebut dapat menampung siswa, berarti terjadi tumpang tindih antara input SD dengan SMP, dan ada yang tidak masuk dalam 
perkiraan input yang seharusnya.

2. Input untuk program wajib belajar

3. Pendidikan dasar juga perlu mempertimbangkan anak-anak yang kemungkinan terlambat masuk sekolah atau justru lulus dengan usia yang jauh lebih muda, karena ada yang terlambat karena mengulang kelas atau anak-anak yang sekarang ikut kelas percepatan.

\section{Indikator Keberhasilan Tahap} Input Program Wajib Belajar Pendidikan Dasar

Jika melihat dari beberapa evaluasi pada input program Wajib Belajar Pendidikan Dasar di atas, maka dapat disimpulkan bahwa jumlah penduduk usia sekolah yang bersekolah pada tingkatan tersebut sudah terserap dengan baik, jika kita kaitkan dengan APM-SD dan APM-SMP yang ada pada tahap proses, walaupun masih ada catatan atau pertimbangan lain yang selama ini tidak ditinjau lebih jauh misalnya anak yang bersekolah di tingkat SD bisa saja diluar usia 7-12 tahun dan di tingkat SMP bisa saja diluar usia 13-15 tahun.

\section{Evaluasi Proses Program Wajar Dikdas}

Proses ditinjau dari indikator dari Goal 2 MDGs Millenium Development Goals BPS (Mencapai Pendidikan Dasar untuk Semua) pada target 3 yaitu Angka Partisipasi Murni

Sekolah Dasar (APM SD), Angka Partisipasi Murni di Sekolah Menengah Pertama (APM SMP) dan Angka Melek Huruf

(AMH) penduduk usia 15-24 tahun.

Tabel 4.2 Indikator Proses Program Wajar Dikdas di DKI Jakarta

\begin{tabular}{|c|c|c|c|}
\hline Tahun & APM-SD & $\begin{array}{c}\text { APM- } \\
\text { SMP }\end{array}$ & AMH \\
\hline 2008 & 93.81 & 71.50 & 98.74 \\
\hline 2009 & 94.07 & 72.02 & 98.94 \\
\hline 2010 & 94.59 & 71.96 & 99.13 \\
\hline 2011 & 89.79 & 68.85 & 98.83 \\
\hline
\end{tabular}

Sumber : Biro Pusat Statistik

Angka partisipasi dalam suatu kegiatan penting diketahui, dengan mengetahui angka partisipasi tersebut dapat dinilai apakah kegiatan tersebut disukai masyarakat atau tidak disukai. Semakin besar angka partisipasi suatu program pendidikan berarti, program, lembaga, daerah tersebut berkualitas, sebaliknya kurang dan peserta banyak berhenti dalam proses pelaksanaan program berarti program, lembaga dan daerah 
tersebut tidak berkualitas. Melihat dari tabel di atas APM-SD dan APMSMP sangat baik, berarti program wajib belajar pendidikan dasar disukai atau didukung oleh masyarakat, walaupun dalam pelaksanaannya mengalami kenaikan dan penurunan di tiap tahunnya, di tahun 2011 justru keduanya mengalami penurunan dari tahun sebelumnya, hal ini bisa disebabkan karena semakin rendahnya angka fertilitas. Penurunan ini akan menyebabkan semakin menurunnya jumlah anakanak yang masuk sekolah dasar. Hal lain yang bisa menjadi alasan penurunan adalah jumlah sekolah yang bisa menyerap lulusan sebelumnya tidak sebanding dengan lulusan yang ada. Bila ukuran seperti perubahan jumlah murid digunakan, bisa jadi ditemukan penurunan jumlah murid di sekolah dasar dengan interpretasi terjadi penurunan partisipasi sekolah, dalam hal ini angka partisipasi murni.

Ukuran atau indikator untuk melihat kualitas sumber daya manusia (SDM) yang terkait dengan proses program wajib belajar salah satunya Angka Melek Huruf (AMH). Berdasarkan tabel di atas, presentase penduduk berusia 15 tahun ke atas berpendidikan minimal tamat SMP/sederajat tiap tahun berkisar sebesar 98\%. Ini menunjukkan kualitas SDM menurut tingkat pendidikan formalnya relatif tinggi, yang berarti setiap 100 penduduk usia 15 tahun keatas ada 98 orang yang melek huruf. Penduduk dapat dikatakan melek huruf jika dapat membaca dan menulis huruf latin atau huruf lainnya.

\section{Evaluasi Proses Program Wajib Belajar Pendidikan Dasar}

Beberapa hal yang dievaluasi dari proses Program Wajar Dikdas ini, yaitu:

1. Dapat diartikan untuk proses program wajib belajar pendidikan dasar di DKI Jakarta sudah baik karena angka partisipasi murni di SD dan angka melek huruf relatif tinggi.

2. Angka partisipasi murni di SMP masih sedang, berarti masih ada lulusan SD yang belum terserap. Berarti program wajib belajar pendidikan dasar 9 tahun harus diiimbangi dengan jumlah sekolah lanjutan yang tersedia. 


\section{Indikator Keberhasilan Tahap Proses Program Wajib Belajar Pendidikan Dasar}

Indikator keberhasilan pada tahap proses wajib belajar pendidikan dasar ini melihat pada nilai prosentase APM-SD, APM-SMP dan $\mathrm{AMH}$, maka disimpulkan bahwa tahap proses cukup berhasil, karena nilai prosentase pada APM-SMP mengalami penurunan. Hal ini dapat dilihat dari nilai prosentase APM-SD tinggi yaitu berkisar $89 \%-95 \%$, yang berarti dari setiap 100 penduduk usia 7-12 tahun ada 8995 orang yang bersekolah. Tetapi, pada nilai prosentase APM-SMP cukup yaitu berkisar 68\%-72\%, yang berarti dari setiap 100 penduduk usia 13-15 tahun ada 6872 orang yang bersekolah.

\section{Evaluasi Produk Program Wajar Dikdas}

Keberhasilan program dapat dilihat dari tercapai-tidaknya dampak program yang terdiri dari :

\section{Indikator Keberhasilan}

Tingkat keberhasilan disini diukur dengan merujuk kepada indikator keberhasilan program yakni sesuai dengan indikator dari Goal 2 MDGs Millenium Development Goals BPS (Mencapai
Pendidikan Dasar untuk Semua) pada target 3. Indikator yang dipakai pemerintah untuk mengukur ketercapaian Program Wajib Belajar 9 Tahun adalah pencapaian Angka Partisipasi Kasar (APK).

$$
\text { Selain mengacu pada }
$$
indikator dari Goal 2 MDGs Millenium Development Goals BPS, pada PP No.47 Tahun 2008 mengenai wajib belajar, evaluasi terhadap pelaksanaan program wajib relajar sebagaimana dimaksud pada ayat (1) sekurang-kurangnya meliputi: tingkat pencapaian program wajib belajar; pelaksanaan kurikulum pendidikan dasar; hasil belajar peserta didik; dan realisasi anggaran. Maka kita dapat melihat pada tingkat pencapaian program wajib belajar yaitu ketercapaian angka partisipasi kasar (APK).

Tabel 4.3 Indikator Produk Program Wajar Dikdas di DKI Jakarta

\begin{tabular}{|c|c|c|c|}
\hline Tahun & APK-SD & APK-SMP & $\begin{array}{c}\text { RATA- } \\
\text { RATA } \\
\text { APK }\end{array}$ \\
\hline 2008 & 110.77 & 95.72 & 103.25 \\
\hline 2009 & 108.70 & 87.65 & 98.18 \\
\hline 2010 & 110.45 & 91.42 & 100.94 \\
\hline 2011 & 98.03 & 90.78 & 94.41 \\
\hline
\end{tabular}

Sumber : Biro Pusat Statistik, diolah.

Rata-rata APK di DKI Jakarta pada tiap tahunnya juga mengalami 
kenaikan dan penurunan. Angka yang terlihat pada tahun 2009 dan 2011 menunjukkan adanya penurunan, tetapi bukan berarti bahwa pada tahun tersebut program wajib belajar pendidikan dasar di DKI Jakarta tidak tercapai. Dapat diilustrasikan ketika Propinsi ABC mengklaim dirinya sebagai wilayah yang sukses melaksanakan wajib belajar 9 tahun. Gubernur menyebutkan bahwa kesuksesan tersebut ditunjukkan oleh jumlah murid SMP yang mencapai 250.000 pada tahun 20xx. Tetapi pemerintah pusat malah memberikan penghargaan kepada Propinsi DEF sebagai daerah yang sukses dengan wajib belajar. Menurut pemerintah, propinsi DEF berhasil meningkatkan angka partisipasi sekolah mencapai 45 persen, sedangkan propinsi A baru mencapai 38 persen.

Hal ini terjadi karena pemerintah menggunakan angka partisipasi sekolah dalam menilai kesuksesan program wajib belajar bukan jumlah murid. Umumnya, terdapat dua ukuran partisipasi sekolah yang utama, yaitu Angka Partisipasi Kasar (APK) dan Angka Partisipasi Murni (APM). Keduanya mengukur penyerapan penduduk usia sekolah oleh sektor pendidikan. Perbedaan diantara keduanya adalah penggunaan kelompok usia "standar" di setiap jenjang pendidikan. Usia standar yang dimaksud adalah rentang usia yang dianjurkan pemerintah dan umum dipakai untuk setiap jenjang pendidikan, yang ditampilkan pada tabel berikut:

Tabel 4.4

\begin{tabular}{|c|c|}
\hline Jenjang & Kelompok usia \\
\hline SD & $7-12$ tahun \\
\hline SMP & $13-15$ tahun \\
\hline SMA & $16-18$ tahun \\
\hline Perguruan tinggi & 19 tahun keatas \\
\hline
\end{tabular}

Angka partisipasi sekolah merupakan ukuran daya serap sistem pendidikan terhadap penduduk usia sekolah. Angka tersebut memperhitungkan adanya perubahan penduduk terutama usia muda. Ukuran yang banyak digunakan di sektor pendidikan seperti pertumbuhan jumlah murid lebih menunjukkan perubahan jumlah murid yang mampu ditampung di setiap jenjang sekolah. Sehingga, naiknya persentase jumlah murid tidak dapat diartikan sebagai semakin meningkatnya partisipasi sekolah. Kenaikan tersebut dapat pula dipengaruhi oleh semakin besarnya jumlah penduduk usia sekolah yang tidak diimbangi dengan 
ditambahnya infrastruktur sekolah serta peningkatan akses masuk sekolah sehingga partisipasi sekolah seharusnya tidak berubah atau malah semakin rendah.

\section{Tingkat Ketuntasan Daerah}

Merujuk pada indikator keberhasilan program di atas, yaitu nilai APK tiap tahun. Tingkat ketuntasan daerah dalam melaksanakan program Wajar Dikdas 9 Tahun dikategorikan:

a. Tuntas pratama, bila APK mencapai $80 \%$ s.d. $84 \%$

b. Tuntas madya, bila APK mencapai $85 \%$ s.d. $89 \%$

c. Tuntas utama, bila APK mencapai $90 \%$ s.d. $94 \%$

d. Tuntas paripurna, bila APK mencapai minimal $95 \%$.

Maka tingkat ketuntasan pada DKI Jakarta di periode 20082011, yaitu:

Tabel 4.5 Tingkat Ketuntasan

Program Wajar Dikdas di DKI

\begin{tabular}{|c|c|c|}
\multicolumn{3}{c}{ Jakarta } \\
\hline \multirow{2}{*}{ Tahun } & $\begin{array}{c}\text { RATA- } \\
\text { RATA } \\
\text { APK }\end{array}$ & Tingkat Ketuntasan \\
\hline 2008 & 103.25 & Tuntas paripurna \\
\hline 2009 & 98.18 & Tuntas paripurna \\
\hline 2010 & 100.94 & Tuntas paripurna \\
\hline 2011 & 94.41 & Tuntas utama \\
\hline
\end{tabular}

Evaluasi Produk Program Wajib Belajar Pendidikan Dasar

Beberapa hal yang dievaluasi dari produk Program Wajar Dikdas ini, yaitu:

1. Jika merujuk pada tingkat ketuntasan yang ditetapkan oleh pemerintah sebagaimana dicantumkan di atas, maka terlihat bahwa tingkat pencapaiannya sudah baik dan dapat dikatakan bahwa program ini sudah berhasil, walaupun pada kenyataannya tiap tahun mengalami turun naik.

2. Namun demikian kami menyarankan agar Program Wajib Belajar Pendidikan Dasar ini dilanjutkan mengingat tujuan dan fungsinya sangatlah strategis dalam mendorong kemajuan bangsa.

\section{Indikator Keberhasilan Produk Program Wajib Belajar Pendidikan Dasar}

Indikator keberhasilan pada tahap produk wajib belajar pendidikan dasar ini melihat pada nilai tingkat ketuntasan program, maka disimpulkan bahwa tahap produk berhasil, karena nilainya pada level ketuntasan yang tinggi yaitu berkisar $94 \%-103 \%$. 


\section{Pembahasan}

Dengan mempelajari data kuesioner dan hasil wawancara dengan para key informan, maka dapat peneliti simpulkan bahwa bukan implementasi atau penerapan dari program ini yang bermasalah, tapi model dan prosedur yang ditetapkan dalam program ini sendirilah yang masih kurang sesuai untuk mencapai outcome atau indikator keberhasilan dan dampak yang diinginkan.

Berdasarkan pada hasil observasi terhadap kesesuaian antara rencana / prosedur yang ditetapkan dalam Program Wajar Dikdas dengan implementasinya di lapangan, maka kita tidak akan melihat adanya kesalahan karena sebagian besar prosedur telah dilaksanakan dengan baik. Namun tetap pada kenyataan atau faktanya bahwa indikator keberhasilan dan dampak yang diinginkan dari program ini belum tercapai dengan baik.

Ada beberapa hal strategis yang dapat peneliti ajukan berkenaan dengan hal tersebut berdasarkan hasil wawancara dan data kuesioner yang disebarkan, yakni:

\section{Isu 1: Perlu dilanjutkan ke program wajib belajar 12 tahun}

Berdasarkan hasil wawancara peneliti dengan nara sumber, semua setuju jika dilanjutkan dengan program wajib belajar 12 tahun. Menurut Bapak Asnelly Darwis yang merupakan pengawas pada tingkat pendidikan dasar, beliau berpendapat bahwa perlu adanya program wajib belajar 12 tahun agar masyarakat dapat mencapai pendidikan yang memadai. Begitu pula ibu Endang Hardjanti dan bapak Saadi yang juga pengawas, beliau menambahkan program ini dapat menanggulangi kemiskinan serta biaya dan sumber daya manusia sudah memenuhi. Menurut ibu $\mathrm{Hj}$. Suharti yang merupakan guru di sekolah dasar negeri, beliau sangat setuju dengan program tersebut karena diharapkan tidak ada anak bangsa yang buta aksara. Didukung oleh ibu Halimah, beliau berpendapat bahwa pendidikan 12 tahun sudah mampu membentuk karakter dan kemampuan anak di bidangnya. Begitu pun bapak Asep Habibunajar yang merupakan kepala sekolah SD dan bapak Yusuf kepala sekolah SMP, beliau menyatakan bahwa program wajar 12 tahun diperlukan pada kondisi saat ini dimana anak-anak minimal berijazah 
SMA/sederajat agar bisa survive dalam kehidupan dan dunia kerja serta bisa lebih siap bersaing dalam dunia global.

Ibu Dwi Wahyuni dan Ibu Balandina yang merupakan guru SMP menanggapi serupa dengan program wajar 12 tahun dimana dengan program tersebut diharapkan masyarakat Indonesia siap bersaing dalam dunia globalisasi dengan terwujudnya SDM yang berkompeten dan bertanggung jawab akan tugasnya. Sedangkan bapak Misbah dan bapak Legiman melihat dari sisi hukum dan sosial dimana kebijakan ini tentu saja sesuai dengan UUD 1945 Pasal 31 mengenai hak dalam mendapatkan pendidikan serta warga negara yang kurang mampu dapat bersekolah sebagai bekal di masyarakat.

Untuk program wajib belajar pendidikan dasar ini memang sudah mendasar ada pada UUD 1945 dan UU lain yang menginginkan pemerintah maupun pemerintah daerah tetap harus menjalankan program tersebut walaupun dengan banyak perbaikan.

\section{Isu 2: Model pengawasan program wajib belajar}

Berdasarkan evaluasi dan indikator keberhasilan di tiap tahap, yang dapat ditinjau kembali adalah model pengawasan yang dilakukan oleh pemerintah dan pihak terkait. Sesuai PP No.47 Tahun 2008 bahwa implementasi pengawasan yang harusnya dilakukan secara berkala terhadap pelaksanaan program wajib belajar oleh Pemerintah, pemerintah provinsi, dan pemerintah kabupaten/kota melihat dari tingkat pencapaian program wajib belajar; pelaksanaan kurikulum pendidikan dasar; hasil belajar peserta didik; dan realisasi anggaran.

Model pengawasan yang selama ini berjalan mungkin belum optimal, perlu dilakukan model pengawasan yang berbeda di lapangan, misalnya ada bantuan dari badan atau pihak independen di luar lingkaran kepemerintahan.

\section{Isu 3 :Sanksi jelas sebagai konsekuensi "Wajib Belajar"}

Berdasarkan hasil wawancara peneliti dengan bapak Marlan yang merupakan kepala sekolah SMP, beliau berpendapat bahwa, salah satu penyebab penerapan program wajib belajar sebelumnya belum optimal dikarenakan tidak adanya sanksi yang nyata untuk orangorang atau daerah yang tidak menjalankan program tersebut. 
Padahal jika melihat dari kata wajib, mka jika hal tersebut tidak dijalankan berarti ada sanksi yang sesuai. Misalnya di Brunei Darussalam sudah menerapkan sanksi yang sesuai dengan hukum "wajib" belajar di negara mereka.

\section{Isu 4: Pembinaan Kesadaran Masyarakat}

Dari hasil penggalian informasi dapat dilihat kurang optimalnya dukungan masyarakat terhadap program wajib belajar pendidikan dasar 9 tahun karena masih banyak masyarakat yang belum sadar akan pentingnya program tersebut. Sejalan dengan pendapat bapak Marlan, bapak Agus Soleh dan bapak Yusuf bahwa peran masyarakat dalam mendukung program wajib belajar masih rendah, maka perlu diadakan sosialisasi akan pentingnya program tersebut bagi masyarakat dan negara. Ditambahkan oleh bapak Legiman dan bapak Asnelly Darwis, bahwa masyarakat disini yang terdekat adalah orang tua, dimana orang tua kurang peduli dan berperan aktif dalam pendidikan anak-anaknya.

Walaupun masih ada yang berpendapat bahwa peran masyarakat dalam hal ini orang tua terhadap pendidikan sudah baik, menurut bapak M. Barid Jamaluddin, ibu Hamilah dan bapak Saadi bahwa peran orang tua terlihat pada adanya komite sekolah dan masyarakat peduli pendidikan. Bahkan peran media sebagai pengawas pada dunia pendidikan juga terlihat ditambahkan bapak Saadi.

\section{Isu 5: Perlu penyesuaian sarana prasarana dan jumlah sekolah}

Menurut pendapat peneliti, saat ini dibutuhkan penyesuaian kurikulum yang benar-benar sesuai dengan kehidupan riil. Senada dengan yang disampaikan oleh ibu Izni Fauziah dan bapak Misbah bahwa kurikulum yang ada masih banyak yang teoretis sehingga belum sesuai dengan output yang diharapkan serta harus berguna dalam aplikasi sehari-hari di masyarakat.

Ditambahkan oleh ibu hamilah bahwa masih banyak siswa belum siap untuk hidup di masyarakat karena materi yang diberikan di sekolah tidak banyak mengarah pada psikomotor siswa. Menurut bapak Taufik, hal ini bisa saja terjadi karena memang kurikulum yang ada memang tidak 
dipersiapkan untuk anak-anak yang siap bekerja.

Begitu pula dengan sarana dan prasarana menurut peneliti masih perlu diperhatikan, walaupun hampir sebagian besar nara sumber menyatakan bahwa sarana dan prasarana yang ada di sekolah sudah menunjang dan memadai untuk proses belajar mengajar di sekolah karena diberikan bantuan oleh pemerintah. Menurut bapak Agus Soleh, sarana dan prasarana di sekolah negeri memang memadai tetapi di sekolah swasta tidak terpenuhi. Ditambahkan ibu Balandina bahwa di daerah-daerah terpencil belum ada pemerataan.

Bapak Marlan dan ibu Hamilah berpendapat fasilitas atau sarana prasarana yang ada belum memenuhi standar pelayanan minimal (SPM) karena keterbatasan lahan serta terkendala dalam hal pengoperasian. Didukung oleh ibu Isni Fauziah dan ibu Pesta Maria YS bahwa gedung belum memadai begitu pula untuk listrik

Sejalan dengan ibu Dwi Wahyuni, peneliti juga berpendapat bahwa perlu ada penyesuaian jumlah sekolah dengan lulusan yang dapat diserap. Jenjang SD sampai dengan SMA berbentuk piramida, dimana jumlah sekolah dasar paling banyak dan jumlah sekolah menengah atas paling sedikit, sehingga banyak lulusan sekolah dasar yang tidak tertampung di SMP dan seterusnya dan tidak banyak pula yang masuk sekolah swasta karena tidak punya banyak biaya.

\section{Isu 6: Perlu pelatihan untuk guru profesional}

Menurut peneliti perlu adanya pelatihan untuk meningkatkan kompetensi guru sejalan dengan meningkatnya tahun dasar untuk program wajib belajar. Senada dengan ibu Pesta Maria YS dan bapak Saadi yang berpendapat bahwa perlu adanya pelatihan atau pendidikan latihan yang terencana matang untuk menjadi guru yang profesional. Hal ini dikarenakan masih adanya kekurangan kompetensi pada guru-guru yang ada, seiring pendapat dari ibu Endang Hardjanti bahwa masih banyak guru yang membuat perangkat pembelajaran meniru perangkat pembelajaran yang lain atau menggunakan tahun sebelumnya. Ditambahkan oleh bapak Misbah bahwa masih banyak guru yang gagap teknologi dan tidak menggunakan metode dan model pembelajaran yang baik dalam proses belajar mengajar. 
Walaupun nara sumber lain juga menyatakan bahwa kompetensi guru yang ada sudah memadai dan kompeten karena sesuai dengan bidang masing-masing serta sekarang rata-rata guru berpendidikan minimal S1 bahkan sudah ada yang menamatkan jenjang S2. dan mendapatkan sertifikasi dari pemerintah.

\section{Rekomendasi}

\section{Keberlanjutan Program Wajar Dikdas dengan perbaikan}

Dengan memperhatikan 5 isu strategis dalam Program yang telah disebutkan sebelumnya, maka kami merekomendasikan beberapa hal pada kegiatan Program Wajar Dikdas khususnya di DKI Jakarta, yaitu:

1. Bahwa program wajib belajar pendidikan dasar sudah baik dan dapat dilanjutkan ke program 12 tahun karena ada keoptimisan berjalannya program tersebut.

2. Perlu dibuat model pengawasan baru dengan melibatkan badan atau pihak independen.

3. Perlu dibuatnya sanksi yang tegas agar program wajib bleajar tersebut benar-benar diterapkan dan didukung oleh berbagai pihak.
4. Perlu adanya pembinaan kesadaran masyarakat akan pentingnya program tersebut dengan melakukan sosialisasi dan penyuluhan.

5. Perlu penyesuaian kurikulum, sarana prasarana dan jumlah sekolah seiring berjalannya program wajib belajar yang baru agar ada keseimbangan antara input dan output yang diharapkan.

6. Perlu diadakannya pendidikan dan pelatihan yang terencana baik untuk para guru-guru agar dapat lebih profesional dan kompeten di bidangnya masingmasing.

\section{KESIMPULAN}

1. Penelitian ini dilakukan untuk mengevaluasi Program Wajib Belajar Pendidikan Dasar periode 2008-2011 di DKI Jakarta dan mengetahui sejauh mana tingkat keberhasilan dari Program tersebut, serta merumuskan rekomendasi kebijakan untuk memperbaiki kegiatan ini di masa yang akan datang.

2. Merujuk pada indikator keberhasilan tahap konteks program wajib belajar pendidikan dasar, maka dapat disimpulkan bahwa implementasi 
hukum yang melandasi program tersebut belum terlaksana dengan baik.

3. Merujuk pada indikator keberhasilan tahap input program wajib belajar pendidikan dasar, maka dapat disimpulkan bahwa jumlah penduduk usia sekolah yang bersekolah pada tingkatan tersebut sudah terserap dengan baik

4. Merujuk pada indikator keberhasilan tahap proses program wajib belajar pendidikan dasar, maka dapat disimpulkan bahwa tahap proses cukup berhasil, karena nilai prosentase pada APM-SMP mengalami penurunan. Hal ini dapat dilihat dari nilai prosentase APM-SMP cukup yaitu berkisar $68 \%-72 \%$, yang berarti dari setiap 100 penduduk usia $13-15$ tahun ada 68-72 orang yang bersekolah.

5. Merujuk pada indikator keberhasilan tahap produk program wajib belajar pendidikan dasar, maka dapat disimpulkan bahwa tahap produk berhasil, karena nilainya pada level ketuntasan yang tinggi yaitu berkisar $94 \%-103 \%$.
6. Ada 6 hal isu strategis yang diangkat berdasarkan hasil wawancara yang dianggap perlu diperhatikan berkenaan dengan hal tersebut, yakni: perlu dilanjutkan ke program wajib belajar 12 tahun, model pengawasan program wajib belajar, sanksi jelas sebagai konsekuensi "Wajib Belajar", pembinaan kesadaran masyarakat, perlu penyesuaian sarana prasarana dan jumlah sekolah sertap pelatihan untuk guru profesional.

\section{Rekomendasi}

Dengan memperhatikan 5 isu strategis dalam Program Wajar Dikdas yang telah disebutkan sebelumnya, maka kami merekomendasikan beberapa hal pada kegiatan Program Wajar Dikdas khususnya di DKI Jakarta, yaitu:

7. Bahwa program wajib belajar pendidikan dasar sudah baik dan dapat dilanjutkan ke program 12 tahun karena ada keoptimisan berjalannya program tersebut.

8. Perlu dibuat model pengawasan baru dengan melibatkan badan atau pihak independen.

9. Perlu dibuatnya sanksi yang tegas agar program wajib bleajar 
tersebut benar-benar diterapkan dan didukung oleh berbagai pihak.

10. Perlu adanya pembinaan kesadaran masyarakat akan pentingnya program tersebut dengan melakukan sosialisasi dan penyuluhan.

11.Perlu penyesuaian sarana prasarana dan jumlah sekolah seiring berjalannya program wajib belajar yang baru agar ada keseimbangan antara input dan output yang diharapkan.

12. Perlu diadakannya pendidikan dan pelatihan yang terencana baik untuk para guru-guru agar dapat lebih profesional dan kompeten di bidangnya masingmasing.

\section{DAFTAR PUSTAKA}

Arikunto, Suharsimi. 2012. Dasardasar Evaluasi Pendidikan, Edisi kedua. Jakarta : Bumi Aksara.

Arikunto, S dan Jabar. 2007. Evaluasi Program Pendidikan. Edisi revisi. Jakarta: Bumi Aksara,

Arikunto, Suharsimi dan Cepi Safrudin, 2009. Evaluasi Program Pendidikan : Pedoman Teoritis Praktis Bagi
Mahasiswa dan Praktisi

Pendidikan, cetakan ketiga, Jakarta : Bumi Aksara,

Dunn, William N. 1994. An Introduction to Public Policy Analysis. Englewood Cliffs: Prentice-Hall,

Easton, David. The Political System, New York: Knopf, 1953, hal.129

Gitoasmoro, Soegimin. 2005. Peran Pendidikan NonFormal Dalam Realisasi Wajib Belajar Pendidikan Dasar, Jurnal Pendidikan Dasar Vol 6 , No 1 h.36

Howlett, Michael and M. Ramesh. 1995. Studying Public Policy: Policy Cycles and Policy Subsystems. Toronto: Oxford University Press,

Islamy, Irfan. 2003. Prinsip-Prinsip Perumusan Kebijakan Negara, Cetakan 12, Jakarta: Bumi Aksara.

Moleong, Lexy J. 2004. Metodologi Penelitian Kualitatif. Bandung: Remaja Rosdakarya, Nugroho, Riant. 2009. Public Policy, Jakarta: Elex Media Komputindo,

Parker, R.S. 1975. Policy and Administration. 
Peterson, Steven and Albert Somit. 2003. Human Nature and

Peraturan Pemerintah Republik Indonesia No 47 Tahun 2008.

Sanders, 1973. The Oral History of Evaluation: The Professional Development.

Stewart, Jr Joseph and James P. Lester, 2000. Public Policy: An Evolutionary Approach, 2nd ed., Belmont, CA.

UU Sisdiknas, 2003. Dasar Konsep Pendidikan Moral, Penerbit : Alfabeta.

Undang-Undang Republik Indonesia No 2 Tahun 1989 Tentang Sistem pendidikan Nasional.
Public Policy : An Evolutionary Approach, Palgrave Macmillan.

Undang-Undang Republik Indonesia Tahun 1945 hasil Amandemen ke-III dalam Sidang Umum MPR tahun 2003. Wahab, Solichin Abdul. 1990. Pengantar Analisis

Kebijaksanaan egara, Jakarta: Rineka Cipta,

Wirawan. 2011. Evaluasi : Teori, Model, Standar, Aplikasi, dan Profesi. Rajawali Press, www.bps.go.id 